\title{
Inter-municipal cooperation in Brazil: the case of solid waste consortia
}

\author{
Dituzaya Panguila da Silva ${ }^{1}$ \\ Hugo Consciência Silvestre ${ }^{2}$ \\ Alfa Aliu Embalo ${ }^{3}$ \\ 1 Instituto Universitário de Lisboa-ISCTE, Lisboa - Portugal \\ 2 Universidade da Integração Internacional da Lusofonia Afro-brasileira / Núcleo de Políticas \& Administração Pública, Redenção / \\ CE - Brazil \\ 3 Instituto Superior de Educação e Ciências de Lisboa-ISEC, Lisboa - Portugal
}

\begin{abstract}
This article aims to describe the engagement of local governments in intermunicipal cooperation and the costs of these arrangements for municipalities. Based on a multiple-case research design, three consortia operating in the Brazilian solid waste sector between 2013 and 2017 were selected and examined. The main findings show that the costs of the intermunicipal cooperation and the costs related to the participation of the municipality in these arrangements increased in the period. However, a parameter estimator calculation shows that such costs are likely to be reduced in the near future. It can also be concluded that smaller local governments (either by population or by $\mathrm{km} 2$ ) are more likely to benefit from intermunicipal cooperation. The study discusses both theoretical and practical implications.
\end{abstract}

Keywords: public cooperation; networks; costs; solid waste; Brazil.

\section{A cooperação intermunicipal no Brasil: o caso dos consórcios de resíduos sólidos}

Esta pesquisa tem como principal objetivo descrever a relação entre a utilização dos consórcios com os custos da cooperação pública e de seu financiamento por parte dos municípios. Pela utilização do desenho de pesquisa de caso múltiplo, selecionaram-se três consórcios a atuar no setor dos resíduos sólidos no Brasil, compreendendo o intervalo de anos entre 2013 e 2017. Em geral, é possível concluir que os custos com os consórcios e dos municípios aumentaram durante o período. Pela estimativa de parâmetros, estima-se que os consórcios possibilitam a redução desses custos. Conclui-se ainda que governos locais de menor dimensão, em número de habitantes e área servida, são mais propensos a potenciar os efeitos da cooperação pública. Implicações teóricas e práticas serão apresentadas e discutidas ao longo do texto.

Palavras-chave: cooperação pública; redes ou networks; custos; resíduos sólidos; Brasil.

\section{Cooperación intermunicipal en Brasil: el caso de los consorcios de residuos sólidos}

En este artículo pretendemos describir la relación entre la cooperación intermunicipal con los costos organizacionales y financieros. Sobre la base de un diseño de investigación de casos múltiples, se seleccionaron tres consorcios operantes en el sector brasileño de residuos sólidos en el período 2013-2017. Los principales hallazgos de este estudio muestran que tanto los costos organizacionales como financieros aumentaron durante el período. Sin embargo, y a partir del cálculo de un estimador de parámetros, es probable que dichos costos se reduzcan en el futuro cercano. También se puede concluir que los gobiernos locales más pequeños (ya sea por población o por $\mathrm{km} 2$ ) tienen más probabilidades de aumentar los efectos de la cooperación pública. Las implicaciones teóricas y prácticas de los hallazgos de este estudio se discuten a lo largo del artículo.

Palabras clave: cooperación pública; redes; costos; residuos sólidos; Brasil.

[Translated version] Note: All quotes in English translated by this article's translator. 


\section{ACKNOWLEDGMENTS}

We are grateful to CNPq financial support to conduct this study, process $n^{\circ} 426771 / 2018-4$ CNPq.

\section{INTRODUCTION}

The use of markets as an alternative to hierarchy or bureaucracy to render public services emerged in the late 1980s. Hierarchy was classified as inefficient in the use of human, technical, financial and material resources, because its main objective was to comply with existing written rules. The excess formalization for performance of tasks did not allow innovation in the traditional public administration model (Osborne, 2006, 2010).

New public management ideas emerged as an alternative to bureaucracy, advocating private sector organizations' participation for delivery of public services. Private participation would occur through the use of markets and competition between operators (Pollitt \& Bouckaert, 2017). Competition was central for successful public service delivery, leading to better efficiency. Market competition would require private organizations to develop their own management techniques, increasing their efficiency, thus guaranteeing organizational survival. For these reasons, private organizations should be involved in delivering public services in order to increase efficiency while reducing costs.

Along with markets and associated competition, decentralization was widely developed (Pollitt, 1990). Decentralization aimed to ensure political, administrative and financial autonomy for the most basic level of public service provision: local governments. The assumption underlying decentralization was that it would allow more efficient and effective public services while reducing operational and financial costs (Denhardth \& Denhardth, 2000).

Private sector organizations' participation in rendering public services became widespread. However it has not been proven that private sector involvement leads to cost reduction (Bel \& Fageda, 2015). Therefore, it became necessary to conceive of new models for providing public services, especially after the global financial crisis of 2008 and Brazil's crisis starting in 2015.

Public cooperation has been discussed as a potential alternative for cost reduction while increasing public service coverage and quality. Public cooperation is not a new phenomenon, but it has become a public sector reform idea within the new public governance approach (Torfing \& Sorensen, 2014). New public governance is based on two basic premises: the participation of social actors in the co-construction of public policies and their co-implementation (Osborne, 2006, 2010). The involvement of social actors, especially citizens, in the co-construction of public policies increases democratization and thus political legitimacy (Peters, 2004). Therefore, it is a new way of governing (Christesen, 2012) based on the principles of responsibility, integrity and transparency (Santos \& Giovanella, 2014).

Cooperation though networks, involving multiple actors, is the most common arrangement for public service delivery (Rhodes, 2007), especially inter-municipal cooperation. On theoretical grounds, inter-municipal cooperation's main goal is cost reduction, to decrease the financial burden on local governments. But do these networks really work? (Provan \& Milward, 1999). Bel, Fageda, and 
Warner (2010) reported that inter-municipal cooperation has potential for cost reduction. Sabourin, Massardier and Sotomayor (2016), however, discussed the rhetorical risks of ineffective public policy implementation, without achieving any service improvements. Caldas and Moreira (2013) argued that the main concern of actors can be centered on processes, while neglecting content and rules, preventing greater effectiveness of policies. Massardier and Sabourin (2013) described the existence of multiple goals of collective action, especially when focusing on local governance and regional development in Latin American.

Due to existing theoretical discussion, it is critical to improve knowledge about this particular social phenomenon. This study describes the relationship between inter-municipal cooperation and operational and financial costs in the solid waste sector in Brazil. Most studies on cooperation focus on Western countries. Empirical evidence from different contexts is needed, such as from Latin America. Inter-municipal cooperation in Brazil has a long tradition, but empirical evidence focuses mostly on health services.

Studies of cooperation in Brazil mostly follow American scholars' approach, which favors knowledge of the predictors leading to cooperation (Abrúcio, Filippim, \& Dieguez, 2013; Abrúcio, Sano, \& Sydow, 2010; Matos \& Dias, 2011, among others). This research locus is due to political and administrative organization attached to the existence of federal, state and local governments. Financing of public services is a major issue due to the presence of an intergovernmental or multilevel spectrum. In the case of Brazil, this research preference can also be justified due to local governments' contextual heterogeneity and its effects on each unit's ability to fulfill citizens' needs. In this study, however, we follow the approach of European scholars. We thus focus on contextual predictors with effects on organizational and operational costs of public services through inter-municipal cooperation (Bel \& Warner, 2015). This is another innovation of this study.

We adopted a multiple case study design (Gerring, 2004) to analyze and compare of selected cases through congruence analysis (Blatter \& Blume, 2008). The inter-municipal cooperatives or consortia were selected through intentional sampling (Jooste \& Scott, 2012). Our sample consists of three consortia operating in the solid waste sector in the states of Rio Grande do Sul, Santa Catarina and Minas Gerais. The data were treated by univariate analysis of variance, and within this by weighted least squares regression and the test of between-subjects effects.

Network governance and its theoretical assumptions are detailed after this introductory section. Then we present the main assumptions of inter-municipal cooperation and the empirical strategy, followed by description and discussion of the results. The paper ends with our concluding remarks.

\section{NETWORK GOVERNANCE}

\subsection{Framework}

Public governance involves governmental and non-governmental actors' participation in public policymaking, aiming at social benefits (Klijn, 2008; Santos \& Giovanella, 2014). Public governance aims to strengthen cooperation between government and citizens as well as between public and 
private sector organizations. The idea is that the participation of multiple actors in the definition and implementation of public services will enhance the ability of governments to provide those services (Bevir \& Rhodes, 2001).

Until the 1980s, hierarchy or bureaucracy was the preferred model for rendering public services. This was justified by the direct supervision with clear organizational authority, whereby both politicians and bureaucrats could more easily be involved in execution of administrative procedures. Tasks were performed according to written rules (Osborne, 2006, 2010). Under a formalized production scheme, control could be better exercised, the reason why this arrangement endured. The oil crises led to rethinking of the organizational arrangement to be adopted and its financing (Pollitt, 1990).

The oil crises resulted in economic slowdown. Consequently, trade declined considerably, thus reducing tax revenues. Demands for public services increased, however, due to the loss of purchasing power of the population. The increased need for social assistance put pressure on the already deficient primary public accounts (Pollitt \& Bouckaert, 2017). Neoliberals criticized the bureaucratic model, arguing that governments should be responsible for public policies but not necessarily for the delivery of services, due to the inherent inefficiency. Therefore, public services should be delivered through the use of markets. Organizational and operational efficiency would be improved when using this arrangement, allowing a reduction of the tax burden (Silvestre, 2010, 2019).

Due to the existing political, economic, and social environments, the new public management framework emerged (Hood, 1991). Through competition between private sector operators, it would become possible to reduce the cost of services.

Along with competition arising with the use of markets, decentralization was another institutional reform strategy. With decentralization, local governments assume greater responsibilities for public services, justified by the greater knowledge of local political and administrative actors regarding citizens' real needs. Along with this decentralization movement, private sector organizations' involvement in delivering public services should be favored (Pollitt \& Bouckaert, 2017).

The participation of private sector organizations for public service delivery in practice has not always reduced costs (Bel \& Warner, 2015). For this reason, public cooperation through networks has been discussed as a potential arrangement to increase public service efficiency while reducing costs.

\subsection{The new public governance}

Still in the 1980s, governmental agencies began to strengthen their relationship with other social actors, especially with civil society organizations and third sector volunteers, among others. Rhodes (2000) identified the proximity between actors as a major incentive to rethink the design and implementation of public policies. Until then, the decision on each program to implement, as well as its execution, was centrally defined, without wide participation of other actors.

The participation of existing actors in defining and implementing public policies is a new public governance concern. The expression was coined by Osborne, in 2006, in an article published in Public 
Management Review. This approach relies on the idea that social actors must be engaged in public policy definition or co-construction. As for execution, co-implementation should be favored, especially through specialized users' knowledge of those services (Osborne, 2006, 2010). Connectedness of social actors to policy definition and implementation is possible due to users' knowledge and time availability, or co-production (Oström, 1996).

The new public governance is thus associated with enhancing the effects of government programs through interaction between governmental and non-governmental actors, citizen participation, the use of networks for public service delivery, the improvement of public management, better transparency, decreased public spending and better efficiency (Bevir \& Rhoes, 2001; Hans \& Klijn, 2008; Klijn, 2008). It involves a new approach by which public policies are negotiated with non-governmental actors. It enables improving government's ability to fulfill citizens' needs (Abrúcio, 1997).

Provan and Milward (1999) identified three governance levels aiming to improve public cooperation. The first is the community level, involving the relationship among the government, the parties wanting to deliver services, and the beneficiaries of those services. It relies on public policy definition. The second is the network level, by which the relations between the government and implementing actors are discussed and aligned. Finally, there is the level of the organization in its participatory relationship with service users. As it is central to the study, we review the network level.

\subsection{Cooperation through networks for public service delivery}

Networks were developed by the phenomenon of decentralization or during the prevalence of the new public management. The Next Steps Initiative was launched in 1988 (Silvestre, 2010). The historic development of the British government after the Second World War demanded an administrative and institutional reform agenda. Decentralization made networks critical for local governments' delivery of public services. Networks were placed in opposition to central power, based on verticality (Bevir \& Rhodes, 2001; Osborne, 2006).

As a concept, networks comprise voluntary cooperation and coordination between two or more units in which the main components may not be included in a single structure (Feiock, 2007; O'Toole \& Meier, 2004). Such units can encompass governments - whether federal, state or municipal - in their relationship with private sector organizations and with nonprofit or voluntary associations. Regardless of their composition, networks' main goal is to improve the decision-making process by developing the process and the effects of policies. The union of organizations to render public services is driven by a mutual, diplomatic and trusting spirit among the partners within the network (Rhodes, 2007). Networks acquire a functional role inside and outside government departments to facilitate policy implementation. They can anticipate managerial limits and existing opportunities (Klijn, Koppenjan, \& Temeer, 1995).

Klijn, Koppenjan, and Termeer (1995) reported that networks rely on interdependencies, the reason why they can be greatly enhanced with the sharing of political, technical and administrative resources 
among cooperative units. Cooperation is voluntary in nature, which facilitates the development of relationships based on reciprocity, mutual respect, commitment and honesty. The factors that affect the quality and quantity of services and their costs are maintained as strategies for local governments to render services as desired.

For public policy implementation through networks, several arrangements can be identified, such as cooperative agreements and inter-municipal cooperation, among others (Agranoff, 2014). Local governments' cooperation is commonly defined as inter-municipal cooperation (Bel, Dijkgraaf, Fageda, \& Gradus, 2010). Inter-municipal cooperation is characterized by a horizontal relationship (Klijn, 2008; Hulst \& Montfort, 2012). Joint efforts are brought to bear on social, environmental, political and economic problems (Cruz, 2001; Feiock, 2007). The cooperating units assume that each actor involved is a capital element for materialization of the common objectives. These objectives draw support from the legitimacy of the political system and the responsibility, transparency and interdependence of the parties.

A major reason for cooperation at the local level is the reduction of public service costs (Leroux \& Carr, 2007). Cost reduction can be achieved through economies of scale, where the average costs of the service decreases due to the greater number of inhabitants and supplied area (Feiock, 2007; Hefetz \& Warner, 2011).

An additional motivation for cooperation is to avoid opportunism when negotiating contracts for services with private sector organizations (Feiock, 2007; Warner, 2011). The costs of contracting and monitoring, or transaction costs (Williamson, 1999), are associated in large part with traditional contracting, by which the public agent hires a private sector organization for service delivery (Shrestha \& Feiock, 2011; Bel, Fageda, \& Mur, 2012). Under such circumstances, private sector organizations' main interests might not be the same as those of public sector organizations. Hence, transaction costs raise administrative costs due to the possibility of incomplete contracts and the need for monitoring and control (Williamson, 1999; Bel, Fageda, \& Mur, 2012).

\subsection{The institutionalization of cooperation in the Brazilian context}

Among other things, Brazil's Constitution of 1988 brought greater decentralization and empowerment of local governments regarding their political, financial and administrative autonomy (Mello, 1997). Although envisaged since the 1930s, cooperation made its greatest progress during the 1980s as a reform approach (Abrúcio, Sano, \& Sydow, 2010). Article 23 of the Constitution allows the existence of cooperation agreements among federal, state and local governments (Linhares et al., 2017). These cooperative agreements can be carried out through metropolitan region entities, inter-municipal consortia and regional development plans (Spink, 2005).

Regarding inter-municipal cooperation through consortia, services are jointly maintained through a traditional horizontal administration. Supported by Law 11,107, of 2005 (Machado \& Andrade, 2014 ), and by Decree 6,017 of 2007, consortia are governed under public law since their financing and/or maintenance depend on public money.

Public cooperation has become a very important theme nationally as a result of needs to expand public services with scarce financing (Abrúcio, Filippim, \& Dieguez, 2013). Local governments' 
administrative capacity has been questioned since the decentralization movement (Laczynski \& Teixeira, 2012). Brazil's local governments $(n=5,570)$ have, for the most part, low financial capacity to maintain services because of their small size (Lima \& Silveira, 2018).

Cunha (2004) stated that only through cooperation can local governments take advantage of economies of scale. This is even more important for municipalities with less than 20 thousand inhabitants, which make up 70\% of the nation's total (Henrichs \& Meza, 2017). In 2018, 3,977 cooperation agreements were identified, mostly involving local governments. Healthcare and solid waste collection are the sectors with the highest number of cooperation agreements. Furthermore, municipalities with fewer than 20 thousand inhabitants account for $72 \%$ of these agreements (Silvestre et al., 2019).

Inter-municipal cooperation in Brazil, through consortia, has the same motivations and concerns as their international counterparts. It will thus be edifying to briefly discuss some studies and the results achieved.

\subsection{Studies and results}

As mentioned, studies of inter-municipal cooperation are based on two approaches (Bel \& Warner, 2015). The first is mainly applied in North America, especially the United States, aiming to identify predictors leading to public cooperation (Feiock, 2007).

These studies' major findings show that engagement in inter-municipal cooperation is due the desire for economies of scale. When facing financial stress, local governments can barely meet users' demands. Inter-municipal cooperation emerges to jointly deliver public services. Through inter-organizational cooperation, economies of scale can be achieved, thus improving public services (Feiock, 2007; Bel, Dijkgraaf, Fageda, \& Gradus, 2010; Hefetz \& Warner, 2011; Hulst \& Montfort, 2012).

This is the approach that has been adopted by most Brazilian scholars. Abrúcio, Filippim, and Dieguez (2013) reported that political decision-making and the identification of the predictors leading to public cooperation are primary concerns. Furthermore, health and water resources have been the focus of most studies (Cruz, 2001; Silveira \& Phillipi, 2008; Mello \& Lago-Peña, 2013).

In turn, European scholars have mainly focused on the costs and effects of public cooperation. Allers and Greef (2018) did not find any reduction of Dutch municipalities' costs from cooperative arrangements. Niaounakis and Blank (2017) found that public cooperation of Dutch local governments leads to cost reduction, explained by the improvement of economies of scale. In Spain, Bel, Fageda, and Mur (2012) and Zafra-Gómez, Prior, Díaz, and López-Hernández (2013) reported that inter-municipal cooperation leads to lower costs. In France, Frère, Leprince, and Paty (2014) did not find any relationship between expenditure levels and inter-municipal cooperation.

Under this 'cost' approach to inter-municipal cooperation, Brazilian scholars have been focusing on the waste collection services. Nauro (2003) reported that cooperative solid waste management is beneficial for small municipalities, because of higher efficiency and lower costs compared to delivery 
of services by single local governments. Calderan (2013) stated that cooperation through consortia improves the administrative capacity of public service delivery, among other advantages. Ferreira and Juca (2017) supported the idea that this consortium capacity can be increased by the development of more effective technologies.

As already mentioned, studies of the solid waste sector in Brazil already exist. However, here we innovate by focusing on the relationship between inter-municipal cooperation and its operational and financing costs.

\section{EMPIRICAL STRATEGY}

Cooperative arrangements are typically developed aiming at cost reduction while enhancing the quantity and quality of service. Local governments' cooperation is thus a potentially beneficial an alternative to the use of hierarchy and markets (Silvestre, Marques, \& Gomes, 2018). Based on the new public governance approach, networks between public sector organizations have been encouraged for public service delivery (Osborne, 2006, 2010). As mentioned, cooperation through networks it is not new. The novelty arises from the systematization of their use to achieve institutional and administrative reform (Torfing \& Sorensen, 2014).

For these reasons, here we describe the relationship between inter-municipal cooperation and its operational and financing costs. This involves identification of which independent and contextual variables are most statistically related to the dependent variables. Through parameter estimation, this study also aims to report the behavior of predictors in the statistical model.

\subsection{Research design and unit of analysis}

Due to the need to relate inter-municipal cooperation through consortia regarding their relationship with local government financing costs, we chose a multiple case study research design (Blaikie \& Priest, 2019). This design's major goal is to compare the units (municipalities) under analysis (Gerring, 2004). For such comparison, we applied congruence analysis. According to Blatter and Blume (2008) and Stewart (2012), the comparison of cases makes it possible to identify, explain and understand the cause and effect relationship of the social phenomenon in counterpoint with the literature review.

The cases of inter-municipal cooperation through consortia were selected by the intentional sampling technique (Jooste \& Scott, 2012), with focus on municipal solid waste management. As stated by Abrúcio, Filippim, and Dieguez (2013) and Abrúcio, Sano, and Sydow (2010), nearly all national studies of inter-municipal cooperation focus on areas other than waste collection services. Hence, this study is innovative.

International studies have proved the existence of a relationship between contextual factors and the costs of the service in question (Bel \& Warner, 2015). Coverage area and the number of residents are usually identified as critical for determining costs, the reason why we selected the following consortia for this study: Cigres, Cirsures and Ecotre, together comprising $(n=) 41$ units of analysis (municipal governments), the first involving 31 local governments, the second seven local governments and the third with three local governments. 
TABLE 1 CONSORTIA MAIN CHARACTERISTICS

\begin{tabular}{|c|c|c|c|c|}
\hline Consortia & Services & Number of units & $\begin{array}{l}\text { Number of } \\
\text { residents }\end{array}$ & Area $\left(\right.$ Mean, $\mathrm{km}^{2}$ ) \\
\hline Cigres (RS) & Waste collection selective/recycling/landfill & 31 & $5.924,87$ & 161,19 \\
\hline Cirsures (SC) & $\begin{array}{l}\text { Waste collection } \\
\text { selective/recycling/landfill }\end{array}$ & 7 & 15.823 & 235 \\
\hline Ecotre (MG) & $\begin{array}{l}\text { Waste selective/recycling/Composting/ } \\
\text { landfill }\end{array}$ & 3 & 40.049 & 311 \\
\hline
\end{tabular}

State abbreviations: $\mathrm{RN}=$ Rio Grande do Norte; $\mathrm{SC}=$ Santa Catarina; $\mathrm{MG}=$ Minas Gerais. Source: Elaborated by the authors based on data collected.

The choice of the period studied was based on two considerations. The first was availability of relevant data on mature consortia. For example, the municipality of Siderópolis joined the Cirsures consortium in 2013. It was necessary to study consortia with a certain stability of the number of members to achieve statistically robust results.

The second was economic conditions, to capture the recent national economic reality. Brazil experienced steady increase in gross domestic product (GDP) until 2014, which had lasted more than a decade. In 2015, the country entered a recession that only ended in 2017, with contraction of GDP, pressuring the public sector accounts. Local governments are highly dependent on the Municipal Participation Fund (FPM), by which they receive transfers from the federal government. These transfers decreased due to the economic downturn. This jeopardized the financing of many essential public services. Based on these two considerations, our study period covered 2013 to 2017.

\subsection{Data}

Data were collected from Observatory of Public Consortia and Federalism (http://www.ocpf.org.br) and the Brazilian Institute of Geography and Statistics (IBGE, 2018). Data collection followed the functional form adopted for the empirical analysis:

$$
Y_{i t}=\alpha C O N_{i, t}+\lambda Y E A R_{i, t}+\beta P O P U_{i}+\chi A R E A_{i}+\mu_{i+} e_{i, t}
$$

Where $\mathrm{Y}_{i t}$

$$
\lambda \text { CToCons }_{i, t}=\beta \text { CCons }_{i, t}+\chi \text { CGLocal }_{i, t}
$$




\section{BOX 1 DESCRIPTION OF VARIABLES}

\begin{tabular}{|c|c|c|}
\hline Variable & Description & Justification \\
\hline \multicolumn{3}{|l|}{ Dependent } \\
\hline Consortium Costs (CCons) & Consortium costs, in Brazilian currency (R\$) & \\
\hline $\begin{array}{l}\text { Local government costs } \\
\text { (CGLocal) }\end{array}$ & $\begin{array}{l}\text { Local government costs of consortia, in Brazilian } \\
\text { currency }(\mathrm{R} \$)\end{array}$ & $\begin{array}{l}\text { Allers and Greef (2018); Niaounakis } \\
\text { and Blank (2017); Bel, Fageda, and Mur } \\
\text { (2012); Zafra-Gómez et al. (2013); Frère, } \\
\text { Leprince, and Paty (2014); Bel and Warner }\end{array}$ \\
\hline $\begin{array}{l}\text { Total costs of consortia } \\
\text { (CToCons) }\end{array}$ & $\begin{array}{l}\text { Total costs of consortia, including local government } \\
\text { financing, in Brazilian currency }(\mathrm{R} \$)\end{array}$ & $(2015)$ \\
\hline \multicolumn{3}{|l|}{ Independent } \\
\hline Consortia (CONS) & $\begin{array}{l}\text { Nominal variable for consortium identification: } \\
\text { Cigres, coded as 1; Cirsures, coded as 2; and } \\
\text { Ecotre, coded as } 3\end{array}$ & Feiock (2007); Plata-Díaz et al. (2014) \\
\hline Year (YEAR) & $\begin{array}{l}\text { Nominal variable to identify pre-recession period } \\
\text { (from } 2013 \text { to 2015), coded as 1, and the } \\
\text { recession period (from } 2016 \text { to 2017), coded as } 2\end{array}$ & Lima and Silveira (2018) \\
\hline \multicolumn{3}{|l|}{ Contextual } \\
\hline Population (POPU) & $\begin{array}{l}\text { Nominal variable where municipalities with less } \\
\text { than } 20 \text { thousand residents are coded as } 1 \text { and } \\
\text { the others as } 2\end{array}$ & $\begin{array}{l}\text { Cunha (2004); Henrichs and Meza (2017); } \\
\text { Cruz and Marques (2012) }\end{array}$ \\
\hline Area (AREA) & $\begin{array}{l}\text { Nominal variable where municipalities with areas } \\
\text { with less than } 157 \text { thousand } \mathrm{km}^{2} \text { are coded as } 1 \\
\text { and the others as } 2\end{array}$ & $\begin{array}{l}\text { Lima and Silveira (2018); Cruz and } \\
\text { Marques (2012) }\end{array}$ \\
\hline
\end{tabular}

Source: Elaborated by the authors based on data collected. 
TABLE 2 DESCRIPTIVE STATISTICS

\begin{tabular}{lccccc} 
& N & Mean & Std. dev. & Minimum & Maximum \\
\hline Dependent & & & & & \\
CCons & 168 & .000001 & .9928745 & -2.6770 & 2.6770 \\
CGLocal & 114 & .000000 & .9902755 & -2.5446 & 2.5446 \\
\hline CToCons & 180 & .000001 & .9932611 & -2.7000 & 2.7000 \\
\hline Independent & 205 & & & & - \\
\hline CONS & 205 & 1.32 & .604 & - & - \\
\hline YEAR & & 1.40 & .491 & - \\
\hline Contextual & 205 & 1.1463 & .35431 & - \\
\hline POPU & 205 & 1.49 & .501 & - \\
\hline AREA & & & & - \\
\hline
\end{tabular}

Source: Elaborated by the authors based on data collected.

\subsection{Dependent variables}

$\lambda C$ ToCons $_{i, t}$. Total costs of the consortia, including local government financing, in Brazilian currency (R\$). Total cost is dependent on the cost of the consortium itself, that is, the operational costs of cooperation for the delivery of solid waste services. However, local government financing must be added. The sum of the two variables reflects the total cost (Niaounakis \& Blank, 2017; Zafra-Gómez et al., 2013).

$\beta C C o n_{i, t^{\circ}}$ Consortium costs, in Brazilian currency $(\mathrm{R} \$)$. Exceptionally, consortium costs are included as a dependent variable in this study. We aim to analyze managerial and operational costs arising from public cooperation. Public cooperation leads, in theory, to cost savings (Allers \& Greef, 2018).

$\chi$ CGLocalit. Public cooperation has been discussed as an alternative to hierarchy and markets, aiming to reduce costs of rendering public services. Measured in Brazilian currency (R\$), this variable captures local governments' financing of consortia. For this reason, it is a dependent variable in this study (Bel \& Warner, 2015).

\subsection{Independent variables}

$\alpha$ CONit. Each consortium is included in the model as an independent variable: Cigres, Cirsures and Ecotre. The consortia formed for inter-municipal cooperation are defined as networks (Feiock, 2007). Because of differences in the number of residents and area, we expect an effect on both operational and financing costs for solid waste services. 
AYEARit. Due to the effects of the economic downturn on the revenues of public sector organizations, the year was included as an independent variable (Lima \& Silveira, 2018). Puye et al. (2018) described the negative effect of local governments' financial stress on cooperative arrangements. In Brazil, the year might be a variable with an effect on operating cost defrayal due to decreased revenue from the FPM.

\subsection{Contextual variables}

According to Bel, Warner, and Hebdon (2012), contextual characteristics in which public sector organizations operate can have an effect on the costs of the services. Thus, we included the following contextual variables.

$\beta P O P U_{i, t}$. The existence of a growing number of residents can reduce costs per capita. According to Cruz and Marques (2012), inputs can be better used for a given level of output through economies of scale. Economies of scale can reduce operational costs as a result of a higher number of residents. In our statistical model, this variable is nominal in nature. Such an option can be is justified due to differences of local populations included in the sample - without recodification it would not be possible to guarantee normal distribution of the variables (Cunha, 2004; Henrichs \& Meza, 2017).

$\chi A ́ R E A i t$. Area, measured in $\mathrm{km}^{2}$, is the second contextual variable included in our statistical model. This is justified by the effects on costs arising from differences regarding the service coverage area, i.e., local governments providing services to a larger area incur higher operating costs (Cruz \& Marques, 2012). In the case of municipal waste service, greater area means higher fuel costs as well as higher costs for fleet maintenance and renewal. Therefore, area was recoded as a nominal variable (Cunha, 2004; Lima \& Silveira, 2018).

\subsection{Data treatment and statistical tools}

A major concern at this stage was due to the normality of the distribution of dependent variables: consortium costs, local government costs of consortia and total costs. At first, we found that normality was not met. To overcome this, these variables were estimated by distributing the cumulative proportion using Blom's formula (1959), by the formula $(r-3 / 8) /(w+1 / 4)$, corresponding to the sum of the weight of the cases that originate the ranking calculation. With this formula, normality of the distribution of residuals was guaranteed, through the Shapiro-Wilk test. The latter requires $\mathrm{p}<0.05$, which was satisfied.

Univariate analysis was performed through regression by weighted least squares, with local units being the weighting variable. Three models were created, in which the costs of consortia, the costs of local governments with consortia and the total costs became dependent variables. Levene's test was used to verify whether the null hypothesis of homogeneity of variance of the errors between groups. This hypothesis was confirmed with $\mathrm{p}=0.277$ for the first model; $\mathrm{p}=0.403$ for the second and $\mathrm{p}=0.090$ for the third. The results are therefore credible from a statistical point of view. 
We also tested the effects between subjects to find whether the independent and control variables have an effect on the dependent variables. This enabled knowing which variables had a statistical effect. Finally, we investigated the parameter estimates considering robust standard errors with a $95 \%$ confidence interval. This allows identifying the direction of the effects, positive or negative, of the statistically related variables. All the analyses were conducted using the Statistical Package for the Social Sciences (SPSS), version 25.

\section{RESULTS AND DISCUSSION}

Graph 1 shows that the average consortium costs increased during the period. Interestingly, 2013 and 2014 were the years with the lowest consortium costs. With the financial crisis of 2015, the maximum expenditure was reached, which decreased in 2016, as expected. Then in 2017, the costs increased to the level of 2015. With respect to local government costs, these were highest in 2015, decreased in 2016 and rose in 2017, although falling shy of the level of 2015. This same pattern occurred with total costs, which were highest in 2015, fell in 2016 and increased slightly in 2017, but remained lower than in 2015.

\section{GRAPH 1 EVOLUTION OF CONSORTIUM COSTS}

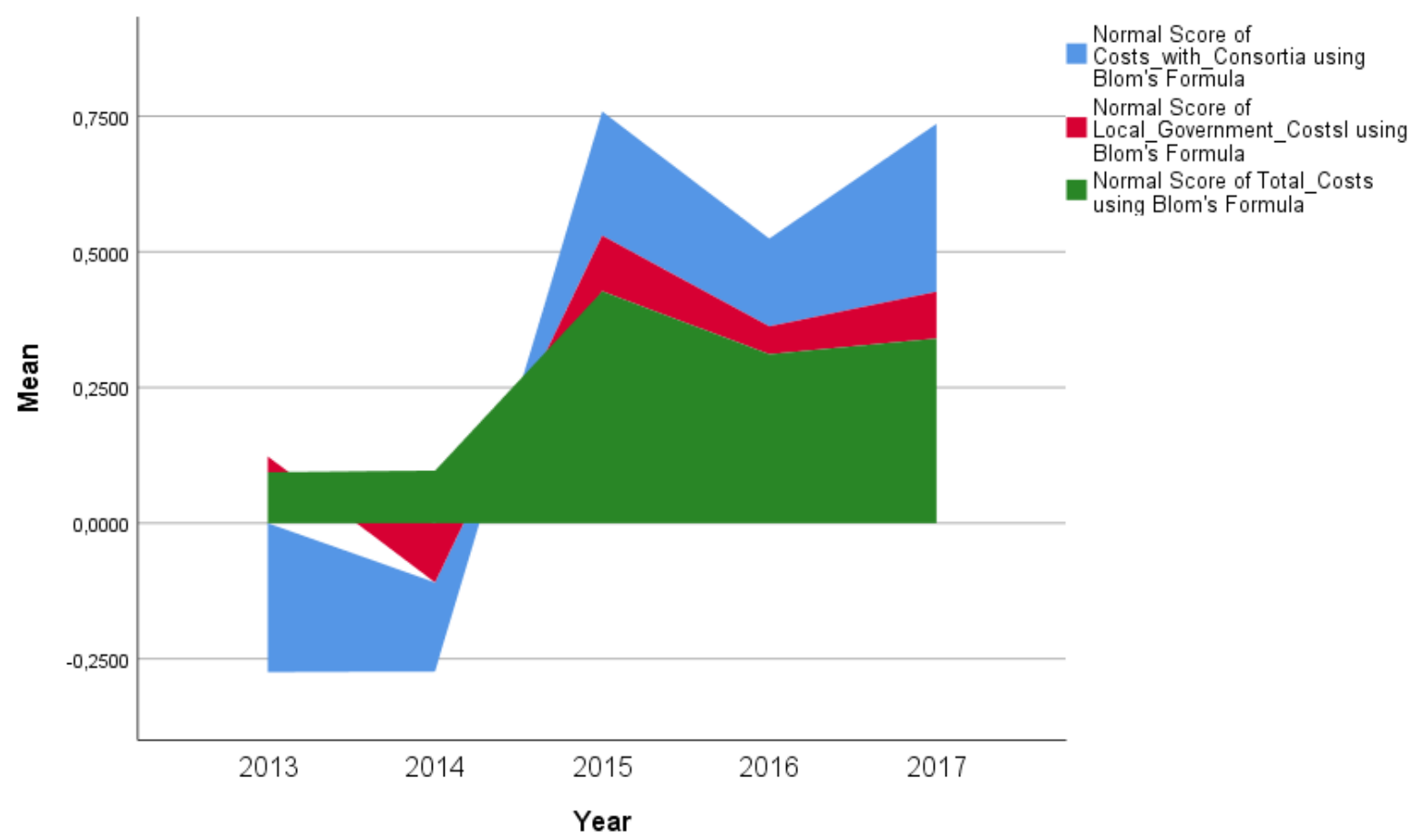

Source: Elaborated by the authors based on data collected. 
A curious finding is that the average total costs were lowest for all the indicators analyzed in the period of economic growth. These costs rose after the start of the recession, when local governments would be expected to reduce their financing of services, including solid waste. This can be explained by the investments planned by the consortia, which were accepted when the cooperation agreement was signed.

In the first model in Table 3 , the variables consortium $(\mathrm{p}=.000)$, area $(\mathrm{p}=.043)$ and year $(\mathrm{p}=.018)$ had an effect on the consortium cost. Among the consortia, Cigres had the lowest average cost $(M=R \$-.4352)$, followed by Cirsures $(M=R \$ .9237)$ and Ecotre $(M=R \$ 1.6350)$. When including the area variable, local governments serving areas up to $157 \mathrm{~km}^{2}$ presented the lowest costs $(M=R \$ 355,222.59)$. As expected, local governments serving larger areas had higher service costs $(M=R \$ 923,494.17)$. Therefore, it can be concluded that consortium and area are the key variables in the quest for cost reduction. Nauro (2003) reported that small municipalities are the ones that most benefit from cooperation through consortium arrangements, a finding confirmed by this study. According to Calderan (2013), cooperation improves local units' administrative capacity, among others, of cooperative structures, aiming to achieve the best use of existing resources. Overall, our findings corroborate the results of other authors, that the synergy created by public cooperation leads to better use of resources and thus better operational performance (Bel et al., 2010; Hefetz \& Warner, 2011).

\section{TABLE 3 TEST OF BETWEEN-SUBJECTS EFFECTS THROUGH WEIGHTED LEAST SQUARES}

\begin{tabular}{|c|c|c|c|}
\hline & Consortium Costs ${ }^{\star *}$ & $\begin{array}{l}\text { Local government } \\
\text { costs }\end{array}$ & $\begin{array}{c}\text { Total costs with } \\
\text { consortia** }\end{array}$ \\
\hline Intercept & $.000 *(80.868)$ & $.000 *(14.675)$ & $.000 *(74.304)$ \\
\hline Consortium & $.000 *(14.797)$ & $.000 *(55.078)$ & $.000 *(13.986)$ \\
\hline Year & $.018^{\star}(5.708)$ & $.936(.006)$ & $.562(.338)$ \\
\hline Population & $.115(2.506)$ & $.002^{*}(10.550)$ & $.606(.268)$ \\
\hline Area & $.043^{*}(4.157)$ & $.008^{*}(7.323)$ & $.004^{*}(8.704)$ \\
\hline Consortium ${ }^{\star}$ Year & $.504(.689)$ & $.620(.481)$ & $.923(.081)$ \\
\hline ConsortiumPopulation & $.531(.395)$ & - & .102 (2.702) \\
\hline ConsortiumArea & $.236(1.414)$ & $.061(3.594)$ & $.952(.004)$ \\
\hline YearPopulation & $.457(.555)$ & $.405(.698)$ & $.782(.077)$ \\
\hline Year ${ }^{\star}$ Area & $.245(1.363)$ & $.891(.019)$ & $.691(.159)$ \\
\hline
\end{tabular}




\begin{tabular}{|c|c|c|c|}
\hline & Consortium Costs $* *$ & $\begin{array}{l}\text { Local government } \\
\text { costs }^{\star \star}\end{array}$ & $\begin{array}{c}\text { Total costs with } \\
\text { consortia }^{\star *}\end{array}$ \\
\hline Consortium${ }^{\star}$ YearPopulation & .509 (437) & - & $.707(.141)$ \\
\hline Consortium ${ }^{\star}$ Year ${ }^{\star}$ Area & $.519(.417)$ & .369 (814) & $.679(.172)$ \\
\hline R-Squared & .678 & .745 & .678 \\
\hline Degrees of freedom & 13 & 11 & 13 \\
\hline F-statistics & $24.938^{\star}$ & $27.060^{\star}$ & $26.921^{*}$ \\
\hline
\end{tabular}

${ }^{*} \operatorname{sig} p<0.05,{ }^{*}$ weighted by local government units

$F$-statistics between parentheses

Source: Elaborated by the authors based on data collected.

In the second model, consortium $(\mathrm{p}=.000)$, population $(\mathrm{p}=.002)$ and area $(\mathrm{p}=.008)$ had an effect on local governments' financing costs. Once again, the Cigres consortium $(\mathrm{M}=\mathrm{R} \$$-.4401) presented the lowest average cost, followed by Cirsures $(\mathrm{M}=\mathrm{R} \$ .7238)$ and Ecotre $(\mathrm{M}=\mathrm{R} \$ 1.5854)$. Average costs of local governments cooperating in Cirsures decreased from $2013(\mathrm{M}=\mathrm{R} \$ 1,346,073.84)$ to $2017(\mathrm{M}=\mathrm{R} \$ 1,098,593.43)$. For the Cigres and Ecotre consortia, costs increased (from $M=R \$ 185,226.75$ to $M=R \$ 316,435.01$ and from $M=R \$ 12,788,041.59$ to $M=R \$ 17,871,816.70$, respectively), in the period. This can be explained by the contracts underpinning the consortia. In these contracts, the local governments commit to a well-defined financing scheme. Thus, the results of this study support the arguments of Allers and Greef (2018) and Frère, Leprince, and Paty (2014), for whom local government costs may not decrease with cooperative arrangements. Nevertheless, higher costs can be counterbalanced by more inclusive and better services.

For the number of residents, this study shows that municipalities with more than 20 thousand residents had higher average costs $(M=R \$ 11,778,677.74)$ than those with smaller populations $(\mathrm{M}=\mathrm{R} \$ 463,815.68)$. The same holds true for area - those with up to $157.1 \mathrm{~km}^{2}$ exhibited lower average costs $(M=R \$ 336,006.02)$ than those with larger area $(M=R \$ 4,488,894.68)$. This again corroborates the main assumptions of Cunha (2004) that cooperation between local governments leads to better economies of scale and thus lower costs.

In the third model, with total costs as the dependent variable, consortium $(p=.000)$ and area $(\mathrm{p}=.004)$ were the variables with a significant effect on total costs. Due to the area of the municipalities that compose it, Cigres had the lowest costs $(M=R \$-.4190)$, followed by Cirsures $(M=R \$ .7785)$ and Ecotre $(M=R \$ 1.8149)$. For the area, the findings are similar, since smaller service areas demand smaller financial resources than larger ones $(M=R \$ 538,574.26$ and $\mathrm{M}=\mathrm{R} \$ 378,6583.23$, respectively).

Based on the results of the between-subjects effects tests, the variables consortium and area served had highest effects on the consortium costs, local government costs and total costs for consortia. 
Curiously, there was no cause-effect relationship when considering the variables together. Furthermore, the population variable only once had an effect on costs when considering local government costs as a dependent variable. Altogether the results are strong due to the high explanatory power, as measured by $\mathrm{R}^{2}$ with a value of $70 \%$.

In a second step, we estimated parameters with robust standard errors (Table 4). We expected decreasing average costs of the Cigres and Cirsures consortia. This was borne out, since the total costs of solid waste disposal of both consortia decreased in both cases. For the financing of Cigres, the reduction of costs was dependent on municipalities with up to 20 thousand residents $(M=R \$-3,222)$.

\section{TABLE 4 SUMMARY OF PARAMETER ESTIMATION WITH ROBUST STANDARD ERRORS}

\begin{tabular}{|c|c|c|c|}
\hline & Consortium Costs & Local government costs & $\begin{array}{c}\text { Total costs with } \\
\text { consortia }\end{array}$ \\
\hline Intercept & $.000^{*}(12.837)$ & $.000^{*}(9.029)$ & $.000 *(16.901)$ \\
\hline Consortium 1 & $.000 *(-0.966)$ & $.000^{\star}(-16.493)$ & $.000^{\star}(-12.780)$ \\
\hline Consortium 2 & $.000^{\star}(-3.710)$ & $.000^{*}(-7.894)$ & $.000^{\star}(-7.011)$ \\
\hline Year 1 & $.001^{*}(-3.348)$ & $.736(-.338)$ & $.995(.006)$ \\
\hline Population 1 & $.002^{*}(-3.222)$ & $.000^{*}(6.768)$ & $.356(.925)$ \\
\hline Area 1 & $.617(.501)$ & $.976(-.030)$ & $.285(-1.073)$ \\
\hline Consortium 1*Year 1 & $.065(1.860)$ & $.464(.735)$ & $.583(-.550)$ \\
\hline Consortium 2*Year 1 & $.149(1.452)$ & $.188(1.324)$ & $.323(-.992)$ \\
\hline Consortium $1{ }^{*}$ Population 1 & $.979(.026)$ & - & $.048^{\star}(-1.994)$ \\
\hline Consortium $1{ }^{*}$ Area 1 & $.231(-1.202)$ & $.034^{\star}(-2.155)$ & $.766(-.298)$ \\
\hline Year $1^{*}$ Population 1 & $.008^{\star}(2.686)$ & $.260(-1.133)$ & $.023^{\star}(2.299)$ \\
\hline Year $1{ }^{\star}$ Area 1 & $.143(-1.474)$ & $.421(-.807)$ & $.467(-.729)$ \\
\hline Consortium $1^{*}$ Year $1 *$ Population 1 & - & - & $.341(-.954)$ \\
\hline Consortium $1{ }^{*}$ Year $1 *$ Area 1 & - & $.276(1.096)$ & $.670(.427)$ \\
\hline
\end{tabular}

* $\operatorname{sig} p<.05$ between parentheses

Source: Elaborated by the authors based on data collected.

It can be concluded that the consortia studied reduce the costs of delivering the service of solid waste collection and disposal. These networks are a strong potential arrangement to enable the respective local governments to reduce costs, as also found by Bel and Warner (2015). 


\section{CONCLUSION}

Inter-municipal cooperation encourages local governments to reduce the costs of the services they deliver (Feiock, 2007; Leroux \& Carr, 2007). This cooperation is more likely in the case of entities performing the same tasks, in close proximity and with the same need to render services (Feiock, 2007; Lamothe \& Lamothe, 2011). It is reasonable to assume that cooperation will reduce costs, but this needs to be empirically proven (Bel \& Warner, 2015).

In this study we describe the relationship between inter-municipal cooperation through consortia and their operational and financing costs. We selected the solid waste sector in Brazil, specifically the analysis of three consortia for the 2013 to 2017 period. The between-subjects effects tests revealed that the consortia and the area covered (measured in $\mathrm{km}^{2}$ ) had an effect on the costs of public cooperation. Decreasing costs were expected for the local governments participating in the Cires and Cirsures consortia. Besides the variable consortium, contextual factors had a major effect on the costs of cooperation. Besides this, we found that the smaller municipalities gain the most benefits when engaging in cooperative agreements. Since around $70 \%$ of Brazilian municipalities have fewer than 20 thousand inhabitants, the results of this study can make a timely contribution to the improvement of Brazilian local governments' public management. As an alternative to delivering services by single municipal government entities or participation of the private sector, the formation of consortia can lead to cost reduction of solid waste collection and disposal services. However, the potential of these arrangements has not yet been fully developed.

Although the statistical tests produced robust results, further studies are still needed for the analysis of consortia and their effects on public service costs. In the case of the solid waste sector in Brazil, studies should cover longer periods. Furthermore, there is a lack of understanding of the reasons for the evolution of these costs, since under favorable economic and financial conditions the costs were lower than during the economic downturn. Finally, the study of inter-municipal cooperation should be extended to other sectors. 


\section{REFERENCES}

Abrucio, F. L. (1997). O impacto do modelo gerencial na administração pública: um breve estudo sobre a experiência internacional recente (Cadernos ENAP, n. 10). Brasília, DF: Escola Nacional de Administração.

Abrucio, F. L., Filippim, E. S., \& Dieguez, R. C. (2013). Inovação na cooperação intermunicipal no Brasil: a experiência da Federação Catarinense de Municípios (Fecam) na construção de consórcios públicos. Revista de Administração Pública, 47(6), 1543-1568.

Abrucio, F., Sano, H., \& Sydow, C. (2010). Radiografia do associativismo territorial brasileiro: tendências, desafios e impactos sobre as regiões metropolitanas. Regiões metropolitanas no Brasil (pp. 197-234). Washington, DC: BID.

Agranoff, R. (2014). Local governments in multilevel systems: Emergent public administration challenges. The American Review of Public Administration, 44(4), supl., 47S-62S.

Allers, M. A., \& De Greef, J. A. (2018). Intermunicipal cooperation, public spending and service levels. Local Government Studies, 44(1), 127-150.

Bel, G., Dijkgraaf, E., Fageda, X., \& Gradus, R. (2010). Similar problems, different solutions: Comparing refuse collection in the Netherlands and Spain. Public Administration, 88(2), 479-495.

Bel, G., Fageda, X., \& Mur, M. (2012). Does cooperation reduce service delivery costs? Evidence from residential solid waste services. Journal of Public Administration Research and Theory, 24(1), 85-107.

Bel, G., Fageda, X., \& Warner, M. E. (2010). Is private production of public services cheaper than public production? A meta-regression analysis of solid waste and water services. Journal of Policy Analysis and Management, 29(3), 553-577.

Bel, G., Hebdon, R., \& Warner, M. E. (2018). Beyond privatisation and cost savings: alternatives for local government reform. Local Government Studies, 44(2), 173-182.

Bel, G., \& Warner, M. E. (2015). Inter-Municipal Cooperation and Costs: Expectations and evidence. Public Administration, 93(1), 52-67.

Bevir, M., \& Rhodes, R. A. W. (2001). Decentering tradition: interpreting British government. Administration \& Society, 33(2), 107-132.
Blaikie, N. (2009). Designing social research (2nd. ed.). Cambridge, UK: Polity Press.

Blatter, J., \& Blume, T. (2008). In Search of Co-variance, Causal Mechanisms or Congruence? Towards a Plural Understanding of Case Studies. Swiss Political Science Review, 14(2), 315-356.

Blom, G. (1958). Statistical elements and transformed beta variables. New York, NY: Wiley.

Boeschen, L., Koss, M. P., Figueredo, A. J., \& Coan, J. A. (2001). Experiential avoidance and posttraumatic stress disorder: a cognitive mediational model of rape recovery. Journal of Aggression, Maltreatment \& Trauma, 4(2), 211-245.

Bryman, A. (2015). Social research methods. (5. ed.). Oxford, UK: Oxford University Press.

Caldas, E. de L., \& Moreira, I. (2013). Políticas de desenvolvimento territorial e intermunicipalidade no Brasil: complementaridades e tensões. Sustentabilidade em Debate, 4(2), 41-61.

Calderan, T. B. (2013). Consórcio público Intermunicipal de Gerenciamento de Resíduos Sólidos Domésticos: um estudo de caso ((Master Thesis). Universidade do Vale do Taquari, Lajeado, RS.

Christensen, T. (2012). Post-NPM and changing public governance. Meiji Journal of Political Science and Economics, 1(1), 1-11.

Cruz, M. D. C. M. T. (2001). Consórcios Intermunicipais de Saúde, Educação e Assistência Social no Estado de São Paulo. In CEPAM (Ed.), Consórcio: uma Forma de Cooperação Intermunicipal. São Paulo, SP: Author.

Cruz, N. F., \& Marques, R. C. (2012). Mixed companies and local governance: no man can serve two masters. Public administration, 90(3), 737-758.

Cunha, R. E. (2004). Federalismo e relações intergovernamentais: os consórcios públicos como instrumento de cooperação federativa. Revista do Serviço Público, 55(3), 5-36.

Denhardt, R. B., \& Denhardt, J. V. (2000). The new public service: Serving rather than steering. Public Administration Review, 60(6), 549-559.

Feiock, R. C. (2007). Rational choice and regional governance. Journal of Urban Affairs, 29(1), 47-63. 
Ferreira, C. F. A., \& Jucá, J. F. T. (2017). Metodologia para avaliação dos consórcios de resíduos sólidos urbanos em Minas Gerais. Engenharia Sanitária e Ambiental, 22(3), 513-521.

Fonseca, F. (2013). Consórcios públicos e as agendas do Estado brasileiro (pp. 29-40). São Paulo, SP: Fundação Perseu Abramo.

Frère, Q., Leprince, M., \& Paty, S. (2014). The impact of intermunicipal cooperation on local public spending. Urban Studies, 51(8), 1741-1760.

Gerring, J. (2004). What is a case study and what is it good for? American Political Science Review, 98(2), 341-354.

Hefetz, A., \& Warner, M. E. (2011). Contracting or public delivery? The importance of service, market, and management characteristics. Journal of Public Administration Research and Theory, 22(2), 289-317.

Henrichs, J. A., \& Meza, M. L. F. G. (2017). Governança multinível para o desenvolvimento regional: um estudo de caso do Consórcio Intermunicipal da Fronteira. Revista Brasileira de Gestão Urbana, 9(1), 124-138.

Hood, C. (1991). A public management for all seasons? Public administration, 69(1), 3-19.

Hulst, J. R., \& Montfort, A. J. G. M. van (2012). Institutional features of inter-municipal cooperation: Cooperative arrangements and their national contexts. Public Policy and Administration, 27(2), 121-144.

Instituto Brasileiro de Geografia e Estatística. (2018). Perfil dos Municípios Brasileiros. Retrieved from https://ww2.ibge.gov.br/home/estatistica/economia/ perfilmunic/2015/default.shtm

Jooste, S. F., \& Scott, W. Richard. (2012). The publicprivate partnership enabling field: evidence from three cases. Administration \& Society, 44(2), 149-182.

Kelly, J. (2007). The curious absence of intermunicipal cooperation in England. Public Policy and Administration, 22(3), 319-334.

Klijn, E.-H. (2008). Complexity theory and public administration: what's new? Key concepts in complexity theory compared to their counterparts in public administration research. Public Management Review, 10(3), 299-317.
Klijn, E.-H., Koppenjan, J., \& Termeer, K. (1995). Managing networks in the public sector: a theoretical study of management strategies in policy networks. Public Administration, 73(3), 437-454.

Laczynski, P., \& Teixeira, M. A. C. (2012). Os limites de um consórcio intermunicipal em condições assimétricas de poder: o caso do Cinpra no Maranhão. Cadernos Adenauer, 12(4), 141-160.

Lamothe, M., \& Lamothe, S. (2011). To trust or not to trust? What matters in local government-vendor relationships? Journal of Public Administration Research and Theory, 22(4), 867-892.

Leroux, Kelly, \& Carr, J. B. (2007). Explaining local government cooperation on public works: Evidence from Michigan. Public Works Management \& Policy, 12(1), 344-358.

Lima, R. C. de A., \& Silveira, R. M. S., Neto. (2018). Secession of municipalities and economies of scale: evidence from Brazil. Journal of Regional Science, 58(1), 159-180.

Linhares, P. T. F. S., Messenberg, R. P., \& Ferreira, A. P. L. (2017). Transformações na federação brasileira: o consórcio intermunicipal no Brasil do início do século XXI. Boletim de Análise Político-Institucional, 12, 67-74.

Machado, J. A., \& Andrade, M. L. C. (2014). Cooperação intergovernamental, consórcios públicos e sistemas de distribuição de custos e benefícios. Revista de Administração Pública, 48(3), 695-720.

Massardier, G., \& Sabourin, E. (2013). Internationalization and dissemination of rural territorial development public policies: model hypotheses for Latin America. Sustentabilidade em Debate, 4(2), 83-100.

Matos, F., \& Dias, R. (2012). Cooperação intermunicipal na bacia do rio Paraopeba. Revista de Administração Pública, 46(5), 1225-1250.

Mello, D. L. (1997). Associativismo como instrumento de desenvolvimento dos governos locais: a experiência brasileira e de outros países. Revista de Administração Pública, 31(6), 55-66.

Mello, L., \& Lago-Peñas, S. (2013). Local government cooperation for joint provision: the experiences of Brazil and Spain with inter-municipal consortia. 
In S. Lago-Peñas \& J. Martinez-Vazquez. (Ed.), The Challenge of Local Government Size (Chap. 9, pp. 221-241). Northampton, UK: Edward Elgar Publishing.

Nagashima, L. A., Barros, C., Jr., Andrade, C. C., Silva, E. T., \& Hoshika, C. (2011). Gestão integrada de resíduos sólidos urbanos-uma proposta para o município de Paranavaí, Estado do Paraná, Brasil. Acta Scientiarum Technology, 33(1), 39-47.

Niaounakis, T., \& Blank, J. (2017). Inter-municipal cooperation, economies of scale and cost efficiency: an application of stochastic frontier analysis to Dutch municipal tax departments. Local Government Studies, 43(4), 533-554.

Osborne, S. P. (2006). The New Public Governance? Public Management Review, 8(3), 377-387.

Osborne, S. P. (Ed.). (2010). The new public governance: Emerging perspectives on the theory and practice of public governance. London, UK: Routledge.

Oström, E. (1996). Crossing the great divide: coproduction, synergy, and development. World development, 24(6), 1073-1087.

O’toole, Laurence J., Jr., \& Meier, K. J. (2004). Public management in intergovernmental networks: Matching structural networks and managerial networking. Journal of public administration research and theory, 14(4), 469-494.

Peters, B. G. (2004). Governance and public bureaucracy: new forms of democracy or new forms of control? Asia Pacific Journal of Public Administration, 26(1), 3-15.

Pollitt, C. (1990). Managerialism and the public services: the Anglo-American experience. Oxford, UK: Blackwell Publishing.

Pollitt, C., \& Bouckaert, G. (2017). Public management reform: a comparative analysis-into the age of austerity. Oxford, UK: Oxford University Press.

Provan, K. G., \& Milward, H. B. (1999). Do networks really work? A Framework for Evaluating Publicsector Organizational Networks. Academy of Management Proceedings. Retrieved from https:// doi.org/10.5465/apbpp.1999.27628083

Puey, E. P., Ferran, J. M., \& Mussons, C. P. (2018). Beyond size: overcoming fragmentation by inter- municipal associations in Spain? The case of Catalonia. International Review of Administrative Sciences, 84(4), 639-658.

Rhodes, R. A. W. (2000). Governance and public administration. Debating governance, 5490.

Rhodes, R. A. W. (2007). Understanding governance: ten years on. Organization Studies, 28(8), 1243-1264.

Sabourin, E. P., Massardier, G., \& Sotomayor, O. (2016). As políticas de desenvolvimento territorial rural na América latina: uma hibridação do referencial e da implementação. Mundos PluralesRevista Latinoamericana de Políticas y Acción Pública, 3(1), 75-98.

Santos, A. M dos, \& Giovanella, L. (2014). Governança regional: estratégias e disputas para gestão em saúde. Revista de Saúde Pública, 48(4), 622-631.

Shrestha, M. K., \& Feiock, R. C. (2011). Transaction cost, exchange embeddedness, and interlocal cooperation in local public goods supply. Political Research Quarterly, 64(3), 573-587.

Silvestre, H. C. (2019). A (Nova) Governança Pública. Brasília, DF: Coleção Gestão Pública ENAP/SBAP.

Silvestre, H. C. (2010). Gestão pública: modelos de prestação no serviço público. Lisboa, Portugal: Escolar Editora.

Silvestre, H. C., Marques, R. C., Dollery, B., \& Correia, A. M. (2019). Shared services in Brazilian local government: Urban development in small counties. Public Administration, 97(3), 686-702.

Silvestre, H. C., Marques, R. C., \& Gomes, R. C. (2018). Joined-up Government of utilities: a metareview on a public-public partnership and intermunicipal cooperation in the water and wastewater industries. Public Management Review, 20(4), 607-631.

Silveira, R. C. E., \& Philippi, L. S. (2008). Consórcios públicos: uma alternativa viável para a gestão regionalizada de resíduos sólidos urbanos. Redes, 13(1), 205- 224.

Souza, R. G. D., \& Cordeiro, J. S. (2010). Mapeamento cognitivo e Balanced Scorecard na gestão estratégica de resíduos sólidos urbanos. Gestão \& Produção, 17(3), 483-496.

Spink, P. (2005). The inter-municipal consortia in Brazil: an institutional introduction. In Anales de $10^{\circ}$ Congresso Internacional del Clad, Santiago, Chile. 
Stewart, J. (2012). Multiple-case study methods in governance-related research. Public Management Review, 14(1), 67-82.

Torfing, J., \& Sørensen, E. (2014). The European debate on governance networks: Towards a new and viable paradigm? Policy and Society, 33(4), 329-344.

Urban, R. C. (2016). Índice de adequação do gerenciamento de resíduos sólidos urbanos como ferramenta para o planejamento: aplicação no estado de São Paulo. Revista Engenharia Sanitária, 21(2), 367-377.
Williamson, O. E. (1999). Public and private bureaucracies: a transaction cost economics perspectives. The Journal of Law, Economics, and Organization, 15(1), 306-342.

Yin, R. K. (2015). Estudo de caso: planejamento e métodos. São Paulo, SP: Bookman.

Zafra-Gómez, J. L., Prior, D., Díaz, A. M. P., \& López-Hernández, A. M. (2013). Reducing costs in times of crises: delivery forms in small and medium sized local government waste management services. Public Administration, 91(1), 51-68.

\section{Dituzaya Panguila da Silva}

https://orcid.org/0000-0002-8683-8351

Master in Public Policy at the University Institute of Lisbon-ISCTE. E-mail: dpsaa2@iscte-iul.pt

\section{Hugo Consciência Silvestre}

https://orcid.org/0000-0001-7654-6577

$\mathrm{Ph} . \mathrm{D}$. in Administration Sciences in the specialty of Public Management; Associate Professor at the Institute of Applied Social Sciences at the University of International Integration of Afro-Brazilian Lusophony (UNILAB); Leader of the Public Policy \& Administration Center (NPAP). E-mail. hmcsilvestre@unilab.edu.br

\section{Alfa Aliu Embalo}

https://orcid.org/0000-0002-4666-0309

Master's student in Municipal Management at the Higher Institute of Education and Sciences of Lisbon-ISEC. E-mail: alfaaliuembalo@hotmail.com 